\title{
Formulation Syrup of Extract of Sarang Semut Plant (Myrmecodia rumphii Becc.) From Merauke
}

\author{
Yorinda Buyang ${ }^{1}$, Yenni Pintauli Pasaribu ${ }^{2}$ \\ Chemistry Education Department \\ Universitas Musamus \\ Merauke, Indonesia \\ 1buyang@unmus.ac.id, 22pasaribu@unmus.ac.id
}

\author{
Ivylentine Datu Pallitin ${ }^{3}$ \\ Physics Education Department \\ Universitas Musamus \\ Merauke, Indonesia \\ 3ivyalentine@gmail.com
}

\author{
Ni Luh Sri Suryaningsih ${ }^{4}$ \\ Agricultural Engineering Department \\ Universitas Musamus \\ Merauke, Indonesia \\ ${ }^{4}$ suryaningsih@unmus.ac.id \\ Taslim Ersam ${ }^{5}$, Yatim Lailun Ni'mah ${ }^{6}$ \\ Chemistry Departement \\ Institut Teknologi Sepuluh Nopember \\ Surabaya, Indonesia \\ beckers@chem.its.ac.id, ${ }^{6}$ nikmah@chem.its.ac.id
}

\begin{abstract}
Sarang semut (Myrmecodia rhumpii Becc.) plants from Merauke Regency generally live on bus wood (Eucalyptus sp.). The results of previous studies found that sarang semut plants from Merauke have the potential as antioxidants in warding off free radicals of $92.6601 \%$. The high antioxidant content encourages the formulation of sarang semut syrup as a ready-to-drink health drink and is accepted by consumers through a description and hedonic test. The overall hedonic test results stated the likes and rather likes of sarang semut syrup products or had an average value of 2.36 for color, 2.59 for aroma and $\mathbf{2 . 7 3}$ for flavor. The results of the description test obtained results in a reddish brown color, the results of the aroma tend to be somewhat smelly (herbal drink likely smells), and a rather sweet taste from the added sugar. The results of the hedonic test for the color, taste and aroma most received by the panelists were the treatment of 45 minutes boiling time with $15 \mathrm{~g}$ of sugar per $250 \mathrm{ml}$ of sarang semut syrup.
\end{abstract}

Keywords-Merauke; sarang semut; hedonic test; Myrmecodia rumphii Becc.

\section{INTRODUCTION}

Indonesia is one of the tropical countries that have quite a lot of plant and animal biodiversity that must be conserved and can be used properly [1]. Most plants are used as medicinal plants. Plant materials in the form of leaves, flowers, fruits, stems, and roots have efficacy as medicines and as raw materials in the manufacture of modern medicine and traditional medicines [2]. The use of plants as traditional medicines reaches more than 1000 species, of which $74 \%$ are wild plants that live in the forest [3].

Papua is one of the provinces in Indonesia that is rich in endemic plants that many people use in their daily lives, both as medicine and food. Until now the use of plants as a source of treatment has been carried out for generations. This is considered to have smaller side effects than treatment derived from chemicals. One of the plants from Papua that is used as medicine is sarang semut plant, called sarang semut.

In Papua, sarang semut plants can be found in central mountain, Puncak Jaya, Jayawijaya, Tolikara, Pengunungan Bintang and Paniai [3]. In addition to the district, Merauke is also a district with abundant sarang semut plants for the Myrmecodia rumphii Becc species. Sarang Semut plants are one of the epiphytic plants from Rubiaceae family, which can be symbiotic with ants and can be said to be epiphytic because they attach to other plants, but do not live parasitically in their hosts.

Sarang semut plants from Merauke Regency generally live on bus wood (Eucalyptus sp.). Generally, Sarang semut plants from Merauke has a distinctive characteristic, namely at the end of the stem forming bubbles, round in shape when young and becoming oblong, shortening or elongated after old. On the outside of this plant is covered with thorns to protect it from herbivorous predators [2]. Sarang Semut Plant have a uniqueness which lies in the interaction of ants and tubers wherein the interior of the Sarang semut plants there are cavities that are interconnected and made into houses by the herd of ants so that the ants feel at home in the plant for a long time so that the reaction occurs naturally chemistry between compounds released by ants with substances contained in them, so this plant is commonly called Sarang semut.

Research on Sarang semut plant (Myrmecodia rumphii Becc.) From Merauke Regency has not been widely carried out. But based on the results of recent research, Sarang semut plant from Merauke have high potential as antioxidants. This was stated from the results of the cytotoxicity test using the Brine Shrimp Lethality Test (BSLT) method where the most active fraction of the BSLT test was fraction 7 with LC50 being $0.4752 \mu \mathrm{g} / \mathrm{mL}$. The antioxidant activity test was carried out using 2,2-diphenyl-2-picrylhydrazyl (DDPH) and it was found that the most active fraction was fraction 5 with radical scavenging of $92,6601 \%$ [4]. 
Antioxidant, the free radical eliminators, are the important issue of research in the medical profession and antiaging field [5]. If we efficient antioxidants enough through food intake, it can help us remove the excess free radicals in our bodies, improve health, delay the disease and prolong life. The antioxidants are mainly derived from food and medical plants, such as fruits, vegetable, cereals, mushrooms, beverages, flowers, spices and traditional medicinal herbs [6]-[8]. These natural antioxidants from plant materials are mainly polyphenols (phenolic acids, flavonoids, anthocyanins, lignans and stilbenes), carotenoids (xanthophylls and carotenes) and vitamins (Vitamin E and C) [9]. Generally, these natural antioxidants, especially polyphenols and carotenoids, exhibit a wide range of biological effects, such as anti-inflammatory, antibacterial, antiviral, anti-aging, and anticancer [10]-[13].

Sarang semut plant by the local community of Merauke, especially in Tomer Village are widely used as traditional medicines, such as anti-cancer, anti-diabetes, and rheumatism. People consume Sarang semut plants by drying them in the sun. Dry Sarang semut plants are then boiled with water for further drinking as medicine. The boiled water of the Sarang semut plant provides a sense of freshness and aroma of leaves so that many people don't like it.

Along with the development of the times, as well as people's lifestyles that are increasingly critical to the consumption of food and beverages to support health, people are more selective in choosing a food product. One of them is the tendency to consume health drinks. Health drinks began to be in great demand by consumers because of the higher human awareness of the importance of healthy living. One of the most sought-after health drinks is a drink made from Indonesian natural ingredients that are known to have bioactive components that are antioxidants.

Referring to the benefits of Sarang semut in people's daily lives and the results of previous research on the antioxidant content in sarang semuts from Merauke and the taste and aroma of sarang semut plants, the sarang semut formulation is made as a health drink. Sarang semut syrup formulation aims to combine the properties of products that are easy to consume, taste and benefits for consumers' health. The sarang semut health drink is made by boiling the Sarang semut and adding sugar to give the flavor of the drink.

\section{METHOD}

This research was conducted at the Chemistry Laboratory, Musamus University in June 2018. Syrup material is made from sarang semuts from Tomer Village, Naukenjerai District, Merauke Regency. The method used is an experiment with boiling time treatment (treatment $\mathrm{A}$ ) which is 3 boiling times 30 minutes, 45 minutes and 60 minutes. Whereas the second treatment, namely treatment $\mathrm{B}$, in the form of additional sweetness in the form of sugar. Treatment B (GP code) consists of 4 levels, namely (0) no added sugar, (2) $12.5 \mathrm{gr}$, (2) $15 \mathrm{gr}$ and (3) $17.5 \mathrm{~g}$ of sugar per $250 \mathrm{ml}$ of sarang semut syrup. So that obtained 12 (twelve) combination treatments. Additional sugar is given when the syrup is still hot (about 70 $\left.{ }^{0} \mathrm{C}\right)$. Sensory testing was carried out to find out the descriptive and hedonic characteristics of ready-to-use syrup products by distributing questionnaires to panelists.

\section{RESULT AND DISCUSSION}

Color, aroma, and taste are factors that influence the taste of food products in general [14], so these three factors are tested to find out the description and hedonic of sarang semut syrup products from Merauke. Test results are presented in the following table.

TABLE I. RESUlTS OF HEDONIC TEST AND DESCRIPTIONOF SIRUP SARANG SEMUT From MERAUKE

\begin{tabular}{|c|c|c|c|c|c|c|}
\hline \multirow[b]{2}{*}{ 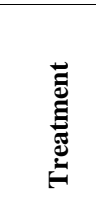 } & \multicolumn{2}{|c|}{ Color } & \multicolumn{2}{|c|}{ Aroma } & \multicolumn{2}{|c|}{ Taste } \\
\hline & 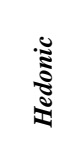 & 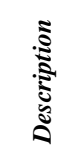 & & 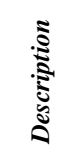 & $\frac{\mathbb{Z}}{\mathbb{Z}}$ & 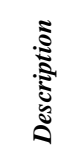 \\
\hline $\mathrm{GP} 0 \mathrm{~A}$ & 2.48 & 3.08 & 2.54 & 1.46 & 3.35 & 1.00 \\
\hline GP 1A & 2.46 & 3.19 & 2.42 & 1.58 & 2.19 & 2.35 \\
\hline GP $2 \mathrm{~A}$ & 2.27 & 3.38 & 2.69 & 1.58 & 2.62 & 2.46 \\
\hline GP $3 \mathrm{~A}$ & 2.19 & 3.35 & 2.62 & 1.58 & 2.31 & 2.73 \\
\hline GP $0 \mathrm{~B}$ & 2.77 & 2.77 & 2.88 & 1.46 & 3.64 & 1.08 \\
\hline GP $1 \mathrm{~B}$ & 2.23 & 3.12 & 2.62 & 1.69 & 2.62 & 2.15 \\
\hline GP 2 B & 2.20 & 3.35 & 2.40 & 2.00 & 2.46 & 2.35 \\
\hline GP 3 B & 2.15 & 3.04 & 2.27 & 1.73 & 2.24 & 2.92 \\
\hline $\mathrm{GP} 0 \mathrm{C}$ & 2.52 & 2.46 & 2.84 & 1.31 & 3.54 & 1.15 \\
\hline GP $1 \mathrm{C}$ & 2.27 & 3.42 & 2.65 & 2.08 & 2.58 & 2.08 \\
\hline GP $2 \mathrm{C}$ & 2.50 & 3.46 & 2.65 & 2.00 & 2.69 & 2.27 \\
\hline GP $3 \mathrm{C}$ & 2.29 & 3.52 & 2.44 & 1.92 & 2.54 & 2.60 \\
\hline
\end{tabular}

Information:

Hedonic: $(1=$ very like; $2=$ like; $3=$ rather like; $4=$ dislike; 5 = very dislike)

Color: $(1=$ redness; 2 = red; 3 = reddish brown; 4 = brown; 5 = dark brown)

Aroma: $(1=$ neutral $/$ ordinary water; $2=$ slightly smelly; $3=$ smell; 4 = very smelly; 5 = other odor)

Taste: $(1=$ bargain; $2=$ rather sweet; $3=$ sweet; $4=$ very sweet; $5=$ too sweet)

The overall hedonic test results stated the likes and rather likes of sarang semut syrup products or had an average value of 2.36 for color, 2.59 for aroma and 2.73 for taste. Tests for taste preference that are more likely to generally like that this product is a health drink product such as herbal products but not too strong. This feeling of not too strong is the strength of this product for the needs of health drinks, especially for children consumers who are usually less fond of herbal products with a strong herbal odor because they are often identified with a bitter taste. This is in line with the 2010 National Socio-Economic Survey (Susenas) statement in the 
study [15] that only $12 \%$ of children aged 6-12 years drink traditional herbs due to trauma and avoid bitter taste. This also supports the diversification of herbal products in the form of ice cream [16], as well as the introduction of herbal medicine using media.

The overall description of the color states that the color of sarang semut syrup is reddish brown. There is almost no color difference between the three boiling times. This is because the result of boiling the sarang semut is obtained from the amount of water and the number of sarang semuts that are the same or the concentration of syrup made is the same. The result of the hedonic test on the color obtained as a whole is like, this is because the color of the sarang semuts syrup obtained is reddish brown color like steeping tea. Some panelists also refer to products as tea products.

Syrup color with different boiling times does not give a significant color difference, it can even be said to have the same color. Boiling is one method of extracting active ingredients from a material that is most often used because it is relatively easier. The same boiling results in color, viscosity, and others can be interpreted as the active ingredients obtained are the same. The active ingredient in sarang semut syrup is antioxidant. The same color shows that the antioxidant activity obtained is the same. This is in accordance with the results of [17] that antimicrobial activity by extraction of different sarang semuts does not produce very different results.

Scent testing gives slightly different results. The difference in boiling time gives a difference in the description of the aroma, namely the longer the boiling time shows the average rating tends to be somewhat smelly. The aroma that the panelist states here are that herbal drinks may smell. Boiling time gives more aroma, this is possible because the number of ingredients contained in the sarang semuts that come out more than the shorter boiling time. This is consistent with the results of other studies which mention the duration of boiling affects the aroma of products derived from the ingredients contained, such as the study of [18]. However, the aroma that is not too strong like this actually supports the existence of health drink products that are useful with aroma that is not too strong so that it is liked by various circles.

The description test results for more flavor shows the amount of added sugar because the more the added amount of sugar the sweetness is more pronounced. The average score obtained is not affected by boiling time but by the addition of sugar which gives a sweet taste to the product. Regarding the results of the hedonic test on taste, in addition to the assessment of sweetness from the results of the description test, the panelists expressed an assessment of the taste of the product as an herbal beverage product. Flavors like herbs are obtained from the basic ingredients of syrup which are sarang semuts, this is in accordance with the results [14], [19] which states that flavor formation that affects the taste of an end product is determined by the raw material.

In general, the results of consumer acceptance of sarang semut syrup products from Merauke are good. However, from the results of the above explanation, it is still necessary to conduct several other studies to support the creation of this ready-to-drink health drink product. The results of the hedonic test for the color, taste and aroma most received by the panelists were the treatment of 45 minutes boiling time with $15 \mathrm{~g}$ of sugar per $250 \mathrm{ml}$ of sarang semut syrup. While based on the description test, the taste most received by the panelists was shown by the addition of $17.5 \mathrm{~g}$ of sugar per $250 \mathrm{ml}$ of sarang semut syrup.

\section{CONCLUSION}

The result of consumer acceptance of sarang semut syrup products from Merauke is good and can be further developed into ready-to-drink health drinks. Overall, based on the results of the hedonic test most received by the panelists was the treatment of 45 minutes of boiling time with $15 \mathrm{~g}$ of sugar per $250 \mathrm{ml}$ of sarang semut syrup. While based on the description test, the taste most received by the panelists was shown by the addition of $17.5 \mathrm{~g}$ of sugar per $250 \mathrm{ml}$ of sarang semut syrup.

\section{ACKNOWLEDGMENT}

We would like to thank the Ministry of Research, Technology And Higher Education for their financial assistance through the DRPM for research schemes collaboration research between universities. Thanks are also conveyed to the Head of the Musamus University Chemical Laboratory for the permission given to conduct this research.

\section{REFERENCES}

[1] H. Roslizawaty, N.Y. Ramadani, Fakhrurrazi, "Antibacterial Activity of Ethanol's Extract and Stew of Ant Plant (Myrmecodia sp.) Against Bakteria Escherichia coli," J. Med. Vet., vol. 7, no. 2, pp. 91-94, 2013.

[2] D.N. Faridah, S. Yasni, A. Suswantinah, and G.W. Aryani, "Chemical and Microbiological Characterization of Instan Bandrek and Nutmeg Syrup (Myristica fragrans)," J. Ilmu Pertan. Indones., vol. 18, no. 1, pp. 43-48, 2013.

[3] H. Subroto and M.A. Saputro, Gempur Penyakit Dengan Sarang Semut. Penebar Swadaya, Depok, 2006.

[4] Y.P. Pasaribu, Y. Buyang, I.D. Pallitin, T. Ersam, and Y.L. Nimah, "Preparation and antioxidant activity of methanol extract of myrmecodiarumphii becc," Indian J. Public Heal. Res. Dev., vol. 9, no. $1,2018$.

[5] Y. Jiang, X. Jiang, and H. Bao, "Antioxidant Synergistic Effect and Formulation Optimization of Several Common Natural Pigments," in International conference on material science and application, 2015, no. Icmsa, pp. 1-5.

[6] H.B.Y. Li, J.J. Zang, D.P. Xu, T. Zhou, Y. Zhou, and S. Li; "Bioactivities and health benefits of wild fruits," Int. J. Mol. Sci, vol. 17, p. 1258, 2016.

[7] H.B.Y. Li, S.K. Li, R.Y. Gan, F.L. Song, L. Kuang, Li, "Total Phenolic contents and antioxidant capacities of 51 edible and wild flowers," Ind.Crop.Prod, vol. 51, pp. 289-298, 2013.

[8] H.G.F. Deng, X. Lin, X.R. Xu, L.L. Gao, J.F. Xie, Li, “Antioxidant capacities and total phenolic content of 56 vegetables," J.Funct.Food, vol. 5, pp. 260-266, 2013.

[9] M.A.A Baiano and del Nobile, "Antioxidant compounds from Vegetatable matrices: Biosyntesis, Occurence, and extraction systems," Crit. Rev. Food Sci. Nutr, vol. 56, pp. 2053-2068, 2015.

[10] C. Peng, X. Wang, J. Chen, R. Jiao, L. Wang, Y.M. Li, Y. Zuo, Y. Liu, L. Lei, Ma, "Biology of ageing and role of dietary antioxidants," BioMed Res.Int, vol. 2014, no. 831-841, 2014.

[11] C. Balmus, I.M. Ciobica, A. Trifan, A. Stanciu, "The Implications of oxidative stress and antioxidant therapies in inflammatory bowel 
disease: Clinical aspects and animal models," Saudi J. Gastroenterol, vol. 22, pp. 3-17, 2016.

[12] M. Wojtunik-Kulesza, K.A. Oniszczuk, A. Oniszczuk, T. Waksmundzka-Hajnos, "The influence of common free radicals and antioxidant on development of Alzheimer's disease," Biomed. Pharmacother, vol. 78, pp. 39-49, 2016.

[13] S. Salomone, F. Godos, and J. Zelber-Sagi, "Natural antioxidants for non-alcoholic fatty liver disease.Molecular targets and clinical perspective," Liver Int, vol. 36, pp. 5-20, 2016.

[14] S.F. dan E. Sribudiani, "Development of Syrup Formulations Made from Pineapple (Ananas comosus L.Merr) Raw Leather and Fruit," SAGU, vol. 8, no. 1, pp. 34-39, 2009.

[15] M. Imron, "Efforts to Introduce Traditional Herbs to Children Through Games," 2017.

[16] N. Hidayah and K. Kunci, "Formulation Study, Phytochemical Characteristics and Sensory of Kencur Rice Traditional Traditional Ice Cream," vol. 15, no. 2, pp. 115-121, 2018.

[17] F.C. dan A.T. Rachmadi, "Utilization of Ants Nest (Myrmecodia pendens) from South Kalimantan as Anti Bacteria," J. Ris. Ind. Has. Hutan, vol. 2, no. 2, pp. 31-35, 2010.

[18] S. Maulina, R.S.S. Santosa, and S. Wasito, "Effect of Boiling Time and Weight of Presses on the Process of Making Milk Tofu with Pineapple Fruit Extract Against Rendemen and Aroma," J. Ilm. Peternak., vol. 1, no. 2, pp. 613-618, 2013.

[19] R.M. Potter, M.P. Dougherty, W.A. Halteman, and M.E. Camire, "Characteristics of wild blueberry-soy beverages," LWT - Food Sci. Technol., vol. 40, no. 5, pp. 807-814, 2007. 